\title{
Protecting the Right to Vote: A Model Voter \\ Challenge Statute
}

In June 1968, primaries were held in certain wards of New Haven, Connecticut, for seats on the Democratic Town Committee. Candidates endorsed by the Democratic Reform Movement, a group of supporters of Senator Eugene McCarthy, were challenging the tight control over the party apparatus held by the Chairman of the Democratic Town Committee. As the day progressed, a large number of voters-most of them young and recently registered supporters of the insurgent candidates-were challenged by local polling officials as not being qualified to vote. All the challenges occurred in wards where the regular party organization had appointed a majority of the election officials. Many of those challenged were forced to show draft cards, drivers licenses, apartment leases, and tax receipts before being allowed to vote. Some were kept from voting entirely. One medical student had to return home for his apartment lease. When he returned to the polling place, offcials demanded his birth certificate, which was not immediately available, and he was not permitted to vote.

Three weeks later, New Haven Superior Court Judge Joseph W. Bogdanski found that election officials in the ward where most challenges had occurred' had "acted in concert by unreasonable, arbitrary and illegal means" to prevent some twenty supporters of the insurgent candidate "from exercising their right to vote," harassing some and "selectively preventing" others from voting. ${ }^{2}$ As the regular party candidate had a margin of only eighteen votes, the court acknowledged that the insurgent candidate would have won had the plaintiffs been allowed to cast their ballots.

Under Connecticut election contest laws, however, a court faced with evidence of misuse of the challenge power is permitted only "to order any voting machine used . . . to be opened and a recount of votes cast."'3 A recount would obviously have been worthless in this instance. Because he found himself unable to order a new election or to add the

1. The 20 plaintiffs in the suit were all from New Haven's Second Ward, since that was the only ward in which the number of persons rejected as voters was large cnough to alter the results of the ward primary. They sucd under a section in Connecticut's election laws allowing any voter or candidate to contest an election. ConN. Gen. Stat. ANN. \& 9-449 (1958).

2. Salter v. Kaplovitz, No. 1116581 (New Haven Superior Court, June 18, 1968), at 3.

3. Conn. Gen. Stat. ANN. § 9.449 (1958). 
plaintiffs' votes to the total of the insurgent candidate, Judge Bogdanski, with admitted regret, ruled for the defendants.

The New Haven case illustrates two aspects of the challenge process which are common to every state in the nation: the potential which the challenge power offers for controlling the right to vote and the inadequacy of legal remedies available for dealing with abuses of such power.

\section{Current Challenge Systems ${ }^{4}$}

Forty-eight states provide for the challenge of prospective voters at the polls on election day. ${ }^{5}$ Responsibility for conducting the election is generally vested in an election board for each precinct or ward, composed of three to five appointed officers. ${ }^{\circ}$ The election statutes usually

4. The subject of the voter challenge and election board powers of determination has been dealt with only collaterally in a few works, most of which were published more than thirty years ago. See, e.g., J. HARRIS, Election Adarinistration is niz UNmed

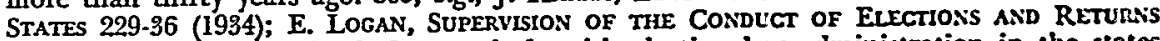
88-92 (1928). These works deal extensively with election law administration in the states but say very little about the statutes themselves or voter challenges. For a very bricf but more recent survey of the nation's election laws, see C.E. Sarri, Votisc AND ElrcIION LAws (1960), which deals with voter challenges, at 41 .

Two excellent early volumes dealing with election law and court decisions relating thereto are G. MCCrARY, Elections (4th ed. 1897), and F. Bricistly, Leadixc Cases ON ELECTIONS (1871).

5. In Hawaii and Vermont, challenge rights for general elections exist only before election day. HawaII REv. LAws $\$ \S 11-15$ to $11-26$ (1955); VT. STAT. ANN. tit. 17, $\$ \S 201-210$ (1958). See also note 16 infra. Such a system seems to have a number of serious disadvantages. For example, it does not take account of the many unavoidable clerical errors with which most registration sheets are filled. Such mistalies may create serious confusion on election day. Some voters might claim on election day that their names were mistakenly omitted from the sheet or that there was a mistake in the listed address. To cover such a contingency, one might require that all voters check for such errors before election day if they wish to vote; however, such $a$ requirement assumes an interest in the franchise and an awareness of the electoral processes which most people lnck. See p. 678 infra. On the other hand, allowing such unlisted voters to vote without challenge obviously opens the door to fraud.

Moreover, since the registration process is closely connected to political parties and their leaders, those in a position to challenge names on the registration lists-the town Registrar, or the Board of Selectmen, or the various prospective poll officials-would undoubtedly refrain from doing so if it served their political purposes. Thus, when election day arrived, there would be no way to prevent illegal votes from getting through.

6. E.g., Arizona-3 members; California-5 members (con vary according to population); Iowa -5 members; Missouri-4 members. Qualifications required of clection board officials are usually literacy and sometimes residency in the precinct in which they are working. See, e.g., CAL. ELECTIONS CODE, $\$ \S 1607,1611$ (West 1961) (read and writc English; voter of precinct in "same general area"); OkLA. STAT. Asw. tit. 26, \$31 (19j5) ("write with reasonable rapidity in a legible form"). Illinois requires only that the officials be "capable and discreet." ILL. ANN. STAT. ch. 46, § 13-1 (Smith-Hurd 1965). The chairman of the election board is called by a variety of names, such as Mloderator (Connecticut), Inspector (Arizona), Judge (Missouri), and Warden (Mainc). The officials are usually appointed by the chief election authority of the town, city, or county, c.g., the town Registrar in Connecticut, CoNN. GeN. STAr. ANN. \& 9.229 (1958), the County Clerk in Colorado, CoL. REv. STAT. ANN. $\$ 49-9-1$ (1958), the County Board of Commissioners in Illinois, Itl. ANN. STat. ch. 46, § 13-1 (Smith-Hurd 1965). 
attempt to make such boards bipartisan by appointing officers from lists submitted by the local central committees of the two major parties; ${ }^{7}$ since most election boards have an odd number of members, the party controlling a majority is often alternated by precinct. ${ }^{8}$

Each member of the election board is usually required to challenge anyone he "knows or suspects"9 or has "good reason to suspect or believe"10 to lack certain qualifications. Such a requirement, however, has had little or no impact on the challenge process itself, since few states provide sanctions for ignoring a "good reason" standard.11

Grounds upon which voters may be challenged are listed in varying degrees of detail or omitted entirely. ${ }^{12}$ The most common grounds for

7. Ala. Code tit. 17, § 125 (1959); Colo. Rev. Stat. ANN, $\S$ 49-9-1, 49.9-6 (1969); NEIl. Rev. STAT. \$ 32-404 (1952).

Some writers argue that the value of having a bipartisan board is at times minimal since officials from both parties may share similar interests. See E. LoGAN, supra note 4 , at 67; J. HARRIs, supra note 4 , at $133,149$.

8. Colo. Rev. Stat. ANN. § 49-9.4 (1963).

9. Iowa Code ANN. \$ 49.79 (1949); NeB. REv. StAT. \$ $32-467$ (1952); N.J. StAT. ANN. $\$ \$$ 19.15-19.18 (1964) ("know, suspect or believe").

10. Alaska Stat. \$ 15.15 .210 (1962) ("good reason to suspect"); Fla. STAT. ANN., $\S 101.23$ (1960) ("if reason to believe'); Mich. CoMp. LAws ANN. § 168.727 (1967) ("know or have good reason to suspect").

11. If the statute establishes a duty to challenge when the official has "good reason" to believe the voter unqualified, a willful failure to challenge would be covered by the penalty section on "willful failure to perform any statutory duty," which appears in most election laws. E.g., MIcH. CoMP. ANN. $\$ 168.931(\mathrm{~m})(1967)$ and note 41 infra. However, the challenger is not expressly warned by the challenge section of the sanctions for failure to follow the "good reason" standard.

12. States which do not collect in a list the grounds for challenge typically provide that anyone who is not a "qualified elector of the precinct" may be challenged. E.g., MICH. Comp. LAws ANN. \& 168.727 (1967). While the exact definition of what constitutes a "qualified elector" is usually not spelled out in detail, it is not left entirely to the challenger's imagination. The basic definition can usually be found in another section, e.g., id. $\S 168.10$, which, though not specified in the challenge provision, usually appcars as a cross reference in annotated versions of the election code. The "qualified elector" provision may itself refer to still other parts of the law: ". . . any person who possesses the qualifications of an elector as prescribed in section 1 of article 2 of the state constitution and who has resided in the city or township 30 days." Id. In turn, the Michigan Constitution, art. 2, $\S \S 1,2$ provides:

Sec. 1. Every citizen of the United States who has attained the age of 21 ycars, who has resided in this state six months, and who meets the requirements of local residence provided by law, shall be an elector and qualified to vote in any election except as otherwise provided in this constitution. The legislature shall define residence for voting purposes.

Sec. 2. The legislature may by law exclude persons from voting because of mental incompetence or commitment to a jail or penal institution.

Additionally, in the provisions on registration, the "qualifications of electors" are again set out. Id. \& 168.492 .

While such extensive (or, at least, extended) definition of the grounds for challenge might be thought to be complete, this is probably not the case. None of these soctions provide that a voter is "not qualified" or "may be challenged" if he has voted beforo in the same election ("repeater") or is not the person he claims to be ("identity"), provisions common to those statutes which spell out the grounds for challenge. Sco note 13 infra. Michigan plainly intends that such persons not vote. See the criminal penaltics which attach to falsely impersonating another person, Mrch. CoMp, LAwS ANN. \& 168.981(I) (1967), using a fictitious name, id. $\S(\mathrm{g})$, voting in a precinct in which one does not 
a challenge are: apparent lack of registration (name not on registration list), age, alienage, non-fulfillment of residency requirements, repeating (voting more than once in that election), identity (prospective voter not whom he claims to be), conviction for felony (without restoration of civil rights), betting on the election, bribery, and illiteracy. ${ }^{13}$

\section{A. Quasi-judicial v. Ministerial Boards}

The states divide about evenly on giving election boards discretionary powers to pass on challenges. Nineteen states ${ }^{14}$ give their boards quasi-judicial ${ }^{15}$ powers to reject a challenged vote (usually by a majority vote of the board). Twenty-five states ${ }^{10}$ prescribe merely ministe-

reside, id. \& (i), or voting more than once, id. $\S(\mathrm{j})$, as well as to violating the blanket prohibition against casting a ballot when one is not a "qualified and registered clector." Id. $\S(\mathrm{h})$. Therefore, an election official is almost certainly permitted to challenge on "identity" or "repeater" grounds and, in fact, would probably be violating his statutory" duty if he failed to challenge someone whom he had good reason to suspect came within these grounds. Id. $\$ \S 168.727,168.931(\mathrm{~m})$. The statute's failure to list the grounds simply in one place, however, makes the law needlessly uncertain. Cf. TEx. Elrction CODE, art. 8.09 (1967); TENN. CODE ANN. § 2-1309 (1955), as amended (Cum. Supp. 1968): S.D. CODE, § 16.1010 (1939); ORE. REv. STAT. \$\$ 250.350 (1968); NEv. REv. STAT., \& 393.303 (1965); MISs. CoDE ANN. \& 14:2-3244 (1957); MD. ANN. CoDE, § 33:16-14 (1961), as amended (Cum. Supp. 1968); ARK. StAT. ANN., \& 9.916 (1956); LA. REv. StAT. ANN. § 18:580 (1967). 13. E.g., ARIZ. REv. STAT. ANN. \$ 16-921 (1956) (identity; residency; repeating; felony. not pardoned; betting; literacy); CAL. Elections CoDE \& 14240 (West 1981) (identity; residency; repeating; alienage; conviction for "infamous crime"; conviction for cm. bezzlement or misappropriation of public money); DEL. CoDE ANN. tit. $15 \$ \$ 4944.4946$ (1953) (identity; bribery); MONT. REV. CODE ANN. \$ 23-1220 (1967) (identity; idioc; or insanity; repeating; felony, not pardoned); UTAH CODE ANN. § 20-7-18 (1953) (identity; residency; citizenship; age; repeating). In at least one state, a voter can be challenged for dueling. WIs. STAT. ANN. \$ 6.92(7) (195i).

14. ARIz. REv. STAT. ANN. \& 16.922 to .926 (1956), as amended (Cum. Supp. 1969); Ars. STAT. ANN. \$ 3-916 (1947); FrA. StAT. ANN. \$§ 101.22.23 (1960), as amended (Cum. Supp. 1969); IDAHo CODE ANN., \$ 34-1025 (1963); KAN. STAT. ANN. \$§ 25-408, 25-411 (1949); kr.

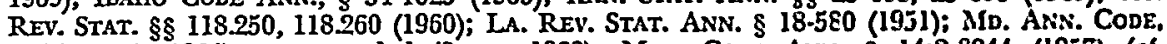
\$ 33:16-14 (1964), as amended (Supp. 1968); Miss. CoDE ANN. \$ 14:2-3244 (1957) (cf. $\S \S 14.2-3129,3108.5,3170$ (primaries)); NEv. REv. STAT. $\$ 293.303$ (1965); N.J. STAT. ANN. \$ 19:15-18, -19, -20, -21, -24 (1964); N.C. GEN. STAT. § 163.88 (1964), as amended (Cum. Supp. 1967); OHo Rev. Code ANN. \$ 3505.20 (Page 1960); PA. Stat. ANN. tit. 25, §§ 30j0. 3053 (1963); S.C. CODE ANN. \$\$ 23-353, 23-383 (1962); TENN. CODE ANN. \$§ 2-1309 to 2-1311 (1955), as amended (Cum. Supp. 1968); VA. CODE ANN. § 24-253, 254 (1964); WWASH. REv. CODE ANN. \$ 29.59. 010, -040,-050 (1965), as amended (Supp. 1968); W. W. Code Aws. \& $3-1-41(1966)$.

15. "Quasi-judicial" will be used in this Note in the sense defined by the Court in Bair v. Struck, 29 Mont. 45, 51, 74 P. 69, 72 (1903): "When the law, in rords or by implication, commits to any officer the duty of looking into facts, and acting upon them. not in a way in which it specifically directs, but after a discretion in its nature judicial, the function is termed quasi-judicial."

16. ALA. CoDE tit. 17, $\S \S 187-91$ (1959); ALASKA STAT., $\S \S 15.15 .130,15.15210$ (1922); Colo. REv. STAT. ANN. \$\$ 49-13-1 to 49-13-6 (1963); GA. CoDE ANN. \$ 34-137 (1962); HAwaII REv. LAws $\S \S 11-15$ to 11-26 (1955); IOWA CODE ANN. $8 \S 49.79$ to 49.81 (1949); ILI. ANN. STAT. ch. 46, § 18-5 (Smith-Hurd 1965); IND. ANN. STAT. \$§ 29-5019, 5020 (1919), as amended (Supp. 1968); MIE. REV. STAT. ANN. tit. 21, $\$ \S 863,925$ (1), 1212 (I965); MLASS. ANN. LAws ch. 54, \$§ 85, 96 (1964), as amended (Cum. Supp. 1968); MIIcr. Comp. Laws ANN. § 168.727 (1967); MIIN. Stat. ANN. § 204.17 (1959); NEb. REv. STAt. \$\$ $32-467$ to -478 (1952); N.H. REV. STAT. ANN. \$ 69:16 (1955); N.Y. ELECTION LAW, $8 \S 17: 225$ (Áckinney 1964); N.D. CENT. CODE \$\$ 16-12-14 (1960), as amended (Cum. Supp. 1967); OKLA. Stat. 
rial $^{17}$ functions to their boards, requiring that the Board issue a ballot to every challenged voter who has fulfilled various statutory requirements. ${ }^{18}$ In six states ${ }^{19}$ the system is a mixture of the two, the officials exercising quasi-judicial powers as to voters challenged on some grounds and ministerial powers as to those challenged on other grounds.

Statutes conferring quasi-judicial authority often provide for an informal trial, with the calling of witnesses on each side, the filing of affidavits and counter-affidavits, and a decision which "may appear right from the proof." 20 Other states require the voter to answer questions "truly and fully" under oath, to take a general oath as to his qualifications to vote, ${ }^{21}$ or to secure written affidavits from two residents of the precinct, ${ }^{22}$ but still reserve the final decision to the discretion of the board. ${ }^{23}$ The central weakness of these statutes is the power

ANN. tit. 26, \& 256 (1955); ORE. Rev. Stat. $\$ \$ 250.350,250.400$ (1968); R.I. Gen. LAwS ANN. $\S \S 17-19-24,17-19-27$ (1956), as amended (Cum. Supp. 1967); S.D. CodE $\$ 16.1010$ (1989); TEX. Election CODE art. 8.09 (1967); UTAH CODE ANN. \& 20.7-18 (1958); VT. STAT. ANN. tit. 17, § 1042 (1968), $\$ \S 203-210$ (1968); Wis. Stat. ANN. $\$ \S 6.92$ to 6.95 (1967); WYo. Srat. ANN., §§ 22:118.107, 118.108 (1957), as amended (Cum. Supp. 1967). Note that Vermont and Hawaii are included as ministerial states, since their election boards have no discretionary powers on election day to refuse votes. In fact, neither state provides for challenge procedures on election day itself, but only prior to election day, with the exception that during a party primary in Hawaii, the challenge procedure is provided for and the election board is given discretion to determine the challenges. See Hawall Rev. Laws $\S 11-103$ (1955).

17. "Ministerial" is used in this Note in the sense defined by the Supreme Court of Vermont in State v. Howard, 83 vt. 6, 14, 74 A. 392, 395 (1909). A ministerial duty is "one regarding which nothing is left to discretion-a simple and definite duty, imposed by law, and arising under conditions admitted or proved to exist." Accord, City of Tacoma v. Peterson, 165 Wash. 461,5 P.2d 1022 (1931).

18. The distinction between quasi-judicial and ministerial boards goes to their dis. cretion to decide the validity of a challenge and thereupon to give or withhold the ballot. Regardless of this distinction, states often impose a duty on the officials to make challenges when they have reasonable grounds to do so; citizens and "party challengers" are also usually allowed to challenge on the same basis. See notes $9 \& 10$ stupra. While this will require making a judgment as to whether there are grounds to cliallenge, it does not amount to a quasi-judicial function, since it does not determine whether or not the challenged voter will be allowed to cast a ballot. Cf. note 92 infra. Similarly, a quasi-judicial board is not "ministerial" because it has no discretion to accept the ballot of a challenged voter who has refused to follow the statutory requirements (taking an oath, answering questions, etc.); its discretionary powers are to reject ballots of voters who have fulfilled those requirements but whom it nonetheless believes are not qualified to vote on other grounds.

19. Cal. Elections Code $\S \S 14240-50$ (West 1961), as amended (Cum. Supp. 1968); Conn. Gen. Stat. ANN. §§ 9-232, 9-232(a) (1958) (cf. id. \$§ 9-170, 9-171, 9-172); Del. Cove ANN. tit. 15, \$\$ 4944-46 (1953), as amended (Cum. Supp. 1966); Mo. REv. STrr. \$\$111.550, 114.210 , 114.220 (1963); Mont. REv. Codes ANN. \$\$ 23-1220 to -1228 (1947); N.M. StAT. ANN. §§ 3-2-50, 3-3-13, 3-3-20, Subsections A(12), (13), (17) (1953), as amended (Cum. Supp. 1967).

For a table of classifications-quasi-judicial, ministerial, or "hybrid"-for all 50 states, see Appendix.

20. N.J. Stat. ANN. §§ 19:15-18, 19:15-24 (1964); KY. Rev. Stat. § 118.260 (1960).

21. Kan. Stat. ANn. \$§ 25.410, -411 (1949); Ohio Rev. Code ANN. $\$ 3505.20$ (Page $1960)$.

22. LA. REV. StAT. ANN. \& 18:580 (1951).

23. Oho Rev. Code ANN. \$ 3505.19 (Page 1960). 
they vest in local officials who, on occasion, may find it in their political interest to misuse the power to determine challenges in order to prevent qualified voters from casting ballots. ${ }^{24}$ Criminal or civil penalties may deter some abuses, ${ }^{25}$ but no remedy other than a new election can restore to every person whose vote has been wrongfully rejected the full value of his ballot. ${ }^{20}$

Two states with quasi-judicial challenge systems overcome part of this problem by providing that if the election board refuses a vote, the challenged voter's ballot is marked and set aside to be ruled on by another body. ${ }^{27}$ Two problems remain, however. First, the fact that the local board has already ruled against their right to vote may discourage voters from casting a special ballot. ${ }^{28}$ Second, determination of the legality of challenged ballots seems inadequately insulated from local political pressures.

In states which confer only ministerial powers on their election boards, challenged voters who satisfy certain statutory requirements are allowed to vote without further delay. Although the procedural steps a voter must follow vary greatly, ${ }^{20}$ most systems involve answering questions as to one's qualifications, taking one or more oaths, and, less frequently, producing supporting affidavits.

While the ministerial structure has some advantages on its face, it suffers from serious infirmities. One difficulty is that states which do

24. See p. 677 infra.

25. See pp. $669-71$ infra.

26. If the election is important, the possibility of criminal or civil liability attaching may not keep some election officials from wrongly denying voters the ballot, provided there are no other means by which their handiwork can be undone. Election contest suits, conceived of as the judicial check on official abuse, are generally ineftective in practice. See pp. 672-73 infra. And in every situation in which there is no contest suit which results in the holding of a new election, those voters who were inproperly denied a ballot will have lost some measure of their right to vote; the right to a secret ballot, for example, frequently is a nullity in an election contest suit. Yet, for a number of reasons, a new election is a disfavored remedy. See note 51 infra.

27. WASH. REv. CODE ANN. \$§ 2959.010, -040,-050 (1965), as amended (Supp. 196\$); W. VA. CODE ANN. \& 3-I-41 (1966). In Washington, the ballot is put in a sealed envelope and sent over to the canvassing board. If the challenger requests, the canvassing board rules on the challenge. If the challenger fails to make such a request, the ballot is accepted and counted. In West Virginia, the ballot is marked and put aside, to be ultimately ruled on by the County Court.

28. See p. 678 infra for discussion of voter apachy.

29. E.g., MAss. GEN. Laws ANN. ch. 54, § 85 (1962); N.Y. Elrction Lily § 17:224 (McKinney 1964). In Massachusetts, if a voter is challenged he is allowed to vote after taking the following general oath: "You do solemnly swear (or affirm) that you are the identical person whom you represent yourself to be, that you are registered in this precinct (or town) and that you have not voted at this elcetion." In New Yort, the voter must go through a three-stage process. First, he must take a preliminary oath, promising to answer all questions "fully and truly." Then, he must answer the questions prescribed in the statute for each particular ground for the challenge. If the ofteials are still dissatisfied, and the roter insists on voting, he must take a general oath (similar to the Massachusetts oath). The precinct board must then allow him to vote. 
not give their local election officers the power to refuse ballots often attempt to guard against fraud by requiring a challenged voter to produce one or more affidavits signed by qualified electors swearing to his qualifications. Some states impose particularly formidable requirements for these supporting affidavits. In Alabama the challenged voter must produce an affidavit by an "elector personally known to some one of the inspectors to be a qualified elector and a freeholder and householder." 30 The affiant has to swear, among other things, that he has known the challenged voter "for the last two years preceding this election," that the latter has been a resident of the state for that time, has resided in the county for one year and the precinct for three months preceding the election. The affiant must also swear that he is himself a qualified elector, freeholder, and householder. ${ }^{31}$ Thus, by the very act of challenging, an official is able to keep the ballot from any voter who is not willing to expend more than a minimal effort in voting or who is not able, despite his eagerness to vote, to produce an affiant "Ireeholder and householder" personally known to a voting official. ${ }^{32}$

An additional problem is that some ministerial boards have arens of discretion so wide that, as with quasi-judicial boards, it is easy for politically motivated appointees to misuse their power. ${ }^{93}$ Yet the basic

30. ALA. CODE tit. 17, $\$ \S 187-191$ (1959).

31. Id. A "freeholder" is one who owns real estate, either as a life estatc or in fcc simple. A "householder" is the head or master of a family. See also Mo. ANN. Srat. $\$ 114.210$ (1963); WYo. STAT. ANN., $\S \S 22: 118.107,118.108$ (1957), as amended (Cum. Supp. 1967); TEX. ELECrion CODE art. 8.09. Wyoming and Missouri require, in addition to the challenged voter's oath, two affidavits signed by qualified clectors in the precinct, swearing to his qualifications. In Texas, the challenged voter must get the oath of a person who is a "well-known" resident of the precinct. It is apparently up to the precinct board to determine who is and who is not "well-known."

32. Although no suit has been brought challenging the constitutionality of this statute under the United States or Alabama constitutions, its validity is doubtful. The holding of the Kentucky Court of Appeals in Queenan v. Russell, 399 S.W.2d 475, 477 (Ky. 1960), represents the general rule in the state courts: "[The legislature] cannot so frame the regulations as to deny the right to vote, either directly or by rendering its exercise so difficult and inconvenient as to amount to a denial." In Russell, the state's burdensome absentee ballot procedures were held to be invalid under Section 6 of the Kentucky Constitution, which is roughly similar to Article 1, Section 83 of the Alabama Constitution. Cf. Wilkinson v. Queen, 269 S.W.2d 223 (Ky. 1054). The cases upholding the right to vote as guaranteed by the federal constitution are discussed infra note 62. State voting regulations which, directly or indirectly, deny citizens the right to vote have been stricken down on numerous occasions. Harman v. Forssenius, 380 U.S. 528 (1965); Terry v. Adams, 345 U.S. 461 (1953); Smith v. Allwright, 821 U.S. 649 (1944); Lane v. Wilson, 307 U.S. 268 (1939); Guinn v. United States, 238 U.S. 817 (1915).

33. For example, in New York, which is recognized as having purcly ministerial election boards, People v. Pease, 27 N.Y. 45, 66 (1863), the challenged voter must answer all questions put to him "fully and truly." New York election officials are also called upon to determine the genuineness of a felon's pardon before allowing him to vote. The court in People v. Pease, supra, pointed out that although the statutory language is not precise on this point, it would seem that such determinations could prevent the challenged voter from casting his ballot. For other states with similar ambiguitics, sce 
shortcoming of most ministerial systems is that they provide no device for identifying ballots illegally cast by challenged voters who are willing to swear falsely in order to vote. Thus, the chances that any suit contesting the election result will be successful are greatly reduced. ${ }^{34}$

\section{B. Criminal and Givil Sanctions}

The classification of an election board as quasi-judicial or ministerial may affect what sanctions can be invoked against it. At common law an election official is liable for damages if he neglects or refuses to perform ministerial duties as required by statute. ${ }^{35}$ When election officials are given discretion in the determination of challenges, however, "they are entitled to the same protection as other judicial officers"30 and are liable only on proof of willfulness or malice. ${ }^{37}$

Griminal prosecutions for wrongful behavior regarding challenges are infrequent. Not only are local prosecutors likely to be subject to political pressures similar to those which led to the voting abuse in the first place, ${ }^{38}$ but even the willing prosecutor will find statutory sanc-

Colo. Rev. Stat. ANn. § 49-13-6 (1963); Minn. Stat. ANn § 204.17 (19j9); Neb. Rev. Stat. § 32-469 (1952); TVIs. STAT. ANN. § 6.94 (1965).

34. The problems of proof created by the inseparability of invalid from valid ballots are discussed at pp. 672-73 infra. The system in Maine, which is perhaps the best ministerial statute, overcomes this difficulty but provides an incficacious remedv. After a challenge, the voter's and challenger's names and the reasons for the challenge are recorded on the ballot, which is then counted along with the others. Only if the number of challenged ballots is large enough to affect the clection results is the validity of each challenge ruled upon by "the Governor and Council." Yet, if they find a sufficiently large number of challenges to be valid, the same problem arises here as in other states: the only remedy is for one of the candidates to sue in court, without specific provision for the calling of a new election. MIE. REv. STAr. ANN. tit. 21, $\$ \$ 863,925(1)$, 1212 (1965).

35. E.g., Frank v. Eaton, 231 N.Y.S. 477, 479 (1928); Lincoln v. Hapgood, 11 Mass. 350 (1814); Bevard v. Hoffman, 18 Mo. 479 (1862); Gillespic v. Palmer, 20 Wis. 544 (1866). Cf. Nixon v. Herndon, 273 U.S. 536, 540 (1926).

36. T. COOLEY, CoNstitumonal Limitations 681 (2d ed. 1871).

37. There election boards act in part quasi-judicially and in part ministerially, the functions are treated separately under the appropriate standard. Thus, "where there is a ministerial act to be done by persons who on other occasions act judicially, the refusal to do the ministerial act is equally actionable, as if no judicial functions were on any occasion entrusted to them." Goetcheus v. Matthewson, 61 N.Y. 420, 431 (1875), quoting Ferguson v. Earl of Kinnoull 9 Cl. \& Fin. 251 (1842).

38. Since June 1968, no criminal charges have been filed against members of the election board involved in the New Haven case, despite clear violations of several sections of Connecticut election law, which specify criminal penalties. CoNs. GEN. STAт. ANN. §§ 9-355, 9-361 (1958).

Where the district attomey is of the same party as the alleged election law violator, prosecutions will probably be rare. Even where the prosecutor belongs to an opposing party, he often will be restrained in prosecuting clection law violations in the cxpectation that when positions are reversed, the favor will be returned. Some commentators argue that in most cases, the theory of opposing political parties acting as watchdors for the other is a myth. See J. HARRis, supra note 4, at 126-48, particularly' at 133: "The thcory" that each side will watch the other is not valid, for many election frauds are committed with the mutual connivance of the election oflicers of both parties. The opposition of 
tions inadequate. ${ }^{39}$ Only a few states have provisions dealing directly with invalid acceptance or rejection of challenged votes ${ }^{40}$ or with the frivolous and indiscriminate use of the challenge power for the purpose of annoying or delaying voters. ${ }^{41}$

The advantage of civil sanctions is that they can be invoked by the aggrieved party without dependence on a district attorney's initiative. Court have disagreed, however, whether a willfulness requirement is wise in civil cases. On the one hand, imposing liability for honest errors of judgment seems unfair, ${ }^{42}$ may discourage citizens from serving as officials, ${ }^{43}$ and may influence officials to be overly cautious in exercising their powers. On the other hand, the difficulty of proving willfulness may effectively preclude the voter from judicial recognition of his rights. Some courts have therefore concluded that any erroneous denial of the ballot, irrespective of malice, should be a compensable wrong. ${ }^{44}$ Judicial authorities nevertheless agree that the need for a

the two political machines to each other, particularly in the large cities, is often a myth, and can never be relied upon ... to safeguard the ballot box." See also E. LocaN, supra note 4 , at $60-81$.

39. Even in the rare cases where a state statute is directed against challenge abuscs (as opposed to other voting frauds), courts will seize upon the traditional justifications for interpreting penal statutes strictly. See State v. Palanque, 133 La. 36, 41, 62 So. 224, 226 (1913); Brown v. Haselman, 79 Ark. 213, 95 S.W. 136 (1906).

40. See Colo. Rev. STAT. ANN. \& 49-21-34 (1963), making it a crime for any clection judge to "willfully and maliciously refuse or neglect to receive the ballot of any quali. fied registered elector who has taken or offered to take the oath prescribed. . "; ALA. CODE tit. 17, \$ 315 (1959): $\$ 100$ fine and up to six months hard labor for willfully excluding vote, "knowing" the challenged voter is entitled to vote, or for accepting a vote without following statutory requirements for challenge; W. VA. CODE ANN. \$ 3.9 .7 (1966), making a misdemeanor of wrongful refusal or allowance of votes punishable by a $\$ 1,000$ fine or one year in jail, maximum, or both.

41. See W. VA. CODE ANN. \$ 3.9.7 (1966), \$100 fine or 90 days in jail for malicious or frivolous challenges; MASS. GEN. LAwS ANN. ch. $56 \$ 31$ (1962): "Any person challeng. ing a qualified voter for purposes of intimidation or of ascertaining how he voted, or for any other illegal purpose shall be punished by a finc of not more than \$100"; Micu. Comp. LAws ANN. \& 168.727 (1967), making it a misdemeanor to assert indiscriminate challenges without good cause for the purpose of "annoying or delaying voters."

If willingness can be proven, however, prosecutors may invoke thrce types of common provisions: (1) knowingly violating the election code, Ill. ANN. STAT. ch. 46 \& $29 \mathrm{~A} \cdot 1$ (Smith-Hurd 1965); PA. STAT. ANN. tit. 25, \$§ 3548, 3350 (1963); (2) willful neglect or refusal to perform statutory duty, CAL. Elections Code $\$ 29002$ (West 1961); ConN. GeN. Stat. ANN. \& 9-355 (1958); Miss. Code ANN. \& 3275 (1957); N.J. Stat. ANN. \& 19:34-83 (1964); (3) election fraud, ARIz. Rev. Stat. ANN. § 16:1310 (1956); PA. STAT. ANN. tit. 25, $\S 3525$ (1963).

42. E.g., Bevard v. Hoffman, 18 Md. 479, 484 (1862).

43. Blake v. Mason, 82 Conn. 324, 329, 73 A. 782, 784 (1909): “[1]t would bc . . . unjust to apply a principle of personal responsibility to honest and fair conduct under such conditions, unwise to interpose so serious an obstacle in the way of the enforcement of proper restraints upon the abuse of the elective franchise, and impolitic to countenance so effective a discouragement of honest and responsible men from accepting a position attendant with such hazards."

44. See Lincoln v. Hapgood, 11 Mass. 350, 354 (1814), which is, despite its age, the most direct statement by a court of this point of view. The court warned that, given the difficulties of proving malice, if election officials were not held absolutcly liable, the challenged voter may be "entirely shut out from a judicial investigation of his right" 
sanction when the wrongful act has been done willfully is especially great. ${ }^{45}$ Damages in such a case are punitive rather than compensatory, "visited on the evil doer for his misconduct rather than as compensation to the party who has suffered the loss. The wrong primarily is against the public, not the individual."10

\section{G. Judicial Remedies}

Statutory provisions for contesting elections in court and equitable relief theoretically offer the citizen who is dissatisfied with the conduct of an election a method to alter the results. In point of fact, statutory inadequacies, judicial reluctance to order new elections, and the practical difficulty of mounting an election suit make these remedies highly ineffective.

Available remedies, such as mandamus, declaratory judgment, and injunction, ${ }^{47}$ are rarely effective in preventing voter challenge abuses. There are obvious practical difficulties in securing relief before the polls close on election day. Where prompt court action is achieved, election officers may be compelled by mandamus to discharge the ministerial duties required by statute, but mandamus is not available to order a particular decision on a voter challenge made by a quasi-judicial election board. ${ }^{48}$ Once the results are in, most courts are reluctant

and may be "prevented, for his life, from exercising a constitutional privilege." Id. Mrassachusetts is still one of the few states with an absolute liability rule, as Lincoln v. Hap. good has never been overruled or modified. See Blanchard v. Stcarns, 16 Miass. (j Ifet.) 298 (1842) (selectmen may be liable in damages for nonmalicious disqualification of voter): Larned v. Wheeler, 140 Mass. 390, 5 N.E. 290 (1886) (a selectman, having only ministerial powers, erased the name of a duly qualified voter; held, liable for damages, though no wilfullness proven).

45. See Bevard v. Hoffman, 18 Md. 479 (1862); Blake v. Mason, 82 Conn. 324, 73 A. 782 (1909); Lincoln v. Hapgood, 11 Mass. 350 (1814); Míorris v. Colorado Mfidland Ry. 48 Colo. 147,109 P. 430 (1910). Note that even Massachusetts, which still applies the absolute liability rule at least in theory, recognizes the importance of a finding of malice in the determination of damages. In order to discourage spurious suits, the court in Hapgood, for example, advised the jury to have regard for the "disposition and temper of mind" discoverable in the act complained of; hence, if no malice were found, only nominal damages should be awarded. 11 Mass. at 357. See G. MCCrarr, supra note 4, at $\S \S 289-301$.

46. Morris v. Colorado Midland Ry., 4\$ Colo. 147, 150, 109 P. 430, 431 (1910). This is one of the more unusual roter damage suits. The plaintiff here sued a railwa) connpany for its negligence in causing plaintiff's arrival to be so delayed that he misced his opportunity to rote. The plaintiff asked the court to award him $\$ 10.000$ for being deprived of the right to vote. The court, finding no malice, ruled that the right to votc is in no sense "an asset of commercial value. It is a privilege bestowed by law, which although of paramount importance, is not such a privilege as an be measured by, or paid for, in dollars and cents, or speculated upon for pecuniary gain." Id.

47. In Brown v. Thurman, 201 Tenn. 474, $300 \mathrm{S.W} 2 \mathrm{~d} 883$ (1957), an injunction to force impounding of absentee ballots was denied as "an infringement upon authority vested in the precinct judges of the election." Id. at $477,300 \mathrm{S.IS}$. CRARY, supra note 4 , at $\$ 387$.

48. Election boards "may perhaps be required by mandamus to perform merely min- 
to involve themselves in the electoral process, especially prior to or in lieu of resort to statutory remedies. ${ }^{49}$

Some states have specific provisions under which any voter or candidate can contest an election, either to instate the candidate who the court decides should have won ${ }^{50}$ or to declare the office vacant, thereby giving rise to the need for a new election. ${ }^{51}$ However, a number of factors prevent contest suits from offering an effective method to affect election results. First, courts are generally very hesitant to overturn election results. ${ }^{52}$ Second, the uniform rule is that the number of voter challenges which were incorrectly decided must be large enough to affect the outcome of the election. ${ }^{53}$ It may be very difficult to assemble evidence of a sufficient magnitude of abuse, especially when it consists of the improper exclusion of voters. ${ }^{54}$ Third, once in court the plaintiff faces serious difficulties in proving that the election was invalid. Under most quasi-judicial and ministerial systems, once the ballot of an unqualified voter is received there is no way to identify it, so reliance must be placed on oral testimony by witnesses whose credibility is sub-

isterial acts in a particular way, and they may be required to exercise their judlcial functions, but they cannot be required by a common law mandamus to decide in a particular manner." People ex rel. Griffith v. Bundy, 107 Col. 102, 105, 109 P.2d 261, 268 (1941). See also Comley ex rel. Harrison v. Wilson, 116 Conn. 36, 163 A. 465 (1932) (a moderator refused to exercise his quasi-judicial powers to recanvass, despite differences between the number of voters checked on registry lists and the number recorded on the voting machines; held, mandamus denied; the moderator's refusal is within his powcr and not an abuse of discretion); Corbett v. Naylor, 25 R.I. 520, 57 A. 303 (1904) (man. damus was denied in suit to compel a moderator to determine which way a vote should be counted, where moderator had used his own proper judgment). See Note, The Role of the Courts in Election Contest Proceedings, 48 MiNN. L. REv. 1181, 1185-86 (1961).

49. See G. MCCrary, supra note 4, at § 396 . Further, after election day, the use of mandamus runs into some serjous legal difficulties even with ministerial boards. For example, mandamus can compel only acts which can be done voluntarily. After clection day, the election board legally ceases to exist and thus, theoretically, cannot voluntarily do anything. For further discussion of this and other related problems, sec Note, supra note 48, 48 MINN. L. REv. 1181, 1186-89.

50. In some jurisdictions this remedy is available in an election contest suit. E.g., CAL. ELECTIONS CODE \& 20087 (West 1961); N.J. Stat. Ann. \$ 19:29.10 (1964). In others it can be sought in a quo warranto proceeding. E.g., Mrcr. Conr. Laws $\$ \S 168.747-49$ (1967); Wis. Stat. ANN. \$ 294.04 (1958). See also G. MCCRARY, supra note 4, $\$ \$ 393,395,996 ;$ Note, supra note 48, 48 MiNN. L. REv. 1181, 1183.

51. E.g., Cal. Elections Code §§ 20086, 20116 (West 1961); N.J. Stat. ANN. \$§ 19:8.29, $19: 29-9$ (1964). Calling a new clection is the less attractive alternative since it involves additional expenses to the state. Furthermore, the availability of a new election serves to encourage an entrenched political organization to cause errors if it fears it will losc the election, since it is likely to be better equipped, financially and politically, to turn out its own voters in the second election than is a group of insurgents.

52. E.g., Teebe v. Smith, 108 Cal. 101, 107, 41 P. 454, 455 (1895).

53. E.g., CAL. Elections Code $\S \S 20021 d$, e (West 1961); N.J. STAT. ANN. § 19:29.1c (1964); NEB. REv. STAT. \& 32-1001 (1952).

54. The difficulties of contest statutes are discussed in Note, supra notc $48,48 \mathrm{M}$ NN. L. REv., 1181. For a lengthy description of an extraordinary election contest controversy, see Thomas, Election Boards and Voting Machines, State of Oklahoma, 4 TuLsA L. REv. 137 (1967). 
stantially reduced by their admission that they have engaged in illegal activity (voting when they were not qualified to do so) or on circumstantial evidence. ${ }^{55}$ Still other problems of proof are encountered when the plaintiff alleges that voters were improperly excluded, which theoretically can occur only if the state has quasi-judicial election boards.50 The voters who testify must be willing to reveal in open court the candidate for whom they would have voted, thereby forfeiting the anonymity which the secret ballot is designed to assure to all citizens. Moreover, and partially in consequence of this lack of secrecy, it is practically very onerous to mount a successful election contest suit. The legwork required to bring the New Haven suit, especially locating those voters who had been wrongly denied the ballot and convincing them it would be worth their time and money to contest the offcials' action, was made possible only by the support of a determined group of insurgents. ${ }^{57}$ Most voters simply do not consider their single vote very important, ${ }^{58}$ so statutory schemes which rely on voter-initiated suits alone to contest the validity of elections in which voter challenges have been misused are largely ineffectual.

\section{Federal Remedies}

Despite a number of federal statutes which make it illegal to interfere with voters casting their ballots, ${ }^{50}$ there have been few prosecutions not involving allegations of racially-motivated discrimination, perhaps because of doubts as to the constitutionality of some of the national legislation. ${ }^{80}$ While there is no question as to the validity of federal

55. In most states a voter's declaration of the candidate for whom he voted is classified as hearsay and is inadmissible as independent evidence; instead, rery clear circumstantial evidence must exist before a vote can be deducted from the total of any candidate. E.g., Hawkins v. Sanguinetti, 98 Cal. App. 2d 278, 220 P.2d 58 (1950); Smith v. Thomns, 121 Cal. 533, 54 P. 71 (1898). The Afodel Statute, which does not provide for clection contest suits, overcomes a similar problem in civil damage actions by creating the re. buttable presumption that the unqualified voter cast his ballot for the defendant. See Model Statute $\S 6(\mathrm{~b})(3)$ infra. Generally, states do not at present allow such a presumption in contest suits. See, e.g., Singletary v. Kelley, 242 Cal. App. $2 d$ 611, 51 Cal. Rptr. 682 (1966).

56. A major contention of this Note, of course, is that the same result (the wrongful exclusion of a qualified voter) often occurs under ministerial systems as well because the making of the challenge is enough to keep from voting those people who do not wish to expend the extra effort required by the challenge procedures.

57. Interview of October 8, 1968, with Thomas Clifford, partner in the law firm of Jacobs, Jacobs, Grudberg \& Clifford, New Haven, Connecticut, and plaintiff' attorncy in Salter v. Kaplovitz, No. 1116581 (New Haven, Conn., Superior Court, June 18, 1985).

58. See notes $79 \& 80$ infra.

59. 42 U.S.C. § 1971 (1964); 42 U.S.C. § 1973 (1964), as amended (Supp. II, 1960); 18 U.S.C. $\$ \$ 241-42$ (1964).

60. Note, The Voting Rights Act of 1965: An Evaluation, 3 HARy. Cw. Ricits.Civ. LIB. L. REV. 357 (1968), especially 362 n.20. 
regulations for conducting elections of federal officials, ${ }^{61}$ it has only recently been established that the Congress may also supervise local elections. ${ }^{62}$ Section 11(a) of the Voting Rights Act of $1965,{ }^{63}$ which applies to all elections, ${ }^{64}$ penalizes election officials who "refuse to permit any person to vote who is entitled to vote under any provision of this Subchapter or is otherwise qualified to vote." 65 Thus, an election official who used the challenge procedures willfully to reject a voter qualified under state law would come within this federal prohibition.

Section 11(b) of the 1965 Act prohibits actions which "intimidate ... any person for voting or attempting to vote" 66 in state as well as federal elections. One federal district court, however, has held 11(b) unenforceable against individual acts of discrimination, in an opinion which has never been explicitly overruled. ${ }^{67}$ Nevertheless, there is good reason to believe that higher courts would probably hold any know-

61. U.S. Const. art. I, \& 4; United States v. Saylor, 322 U.S. 385 (1944); United States v. Mosley, 238 U.S. 383 (1915); Ex Parte Yarborough, 110 U.S. 651 (1884).

62. South Carolina v. Katzenbach, 383 U.S. 301 (1966), explicitly affirms the power of Congress to "use any rational means to effectuate the constitutional prohibition of racial discrimination in voting." 383 U.S. at 324 . While the Court was there addressing itself to the constitutionality under the fifteenth amendment of the procedures established by the 1965 Voting Rights Act to overcome racial discrimination preventing Southern blacks from registering and voting, the power to prohibit discrimination of a non-racial character would be encompassed within the equal protection clause of the fourteenth amenclinent. The Court has had frequent occasion of late to hold that all voters must be trcatcd equally in state as well as federal elections. Reynolds v. Sims, 377 U.S. 533 (1964). See also Wesberry v. Sanders, 376 U.S. 1 (1964); Baker v. Carr, 369 U.S. 86 (1962). "Undeniably, the Constitution of the United States protects the right of all qualified citizens to votc, in state as well as federal elections ... And history has seen a continuting expansion of the scope of the right of suffrage in this country." 377 U.S. at 554-55. The Congrcss has broad powers under the fifth section of the fourteenth amendment to pass legislation designed to enforce the guarantees of the equal protction clause. Katzenbach v. Morgan, 384 U.S. 641 (1966); United States v. Guest, 383 U.S. 745 (1966).

63. 42 U.S.C. \& $1973 i$ (a) (Supp. II, 1966).

64. 42 U.S.C. \$\$ 1973c(a), 1973l(c)(1) (Supp. II, 1966).

65. 42 U.S.C. \& 1973 i(a) (Supp. II, 1966) (emphasis added).

66. 42 U.S.C. \$ 1973 i(b) (Supp. II, 1966).

67. United States v. Harvey, 250 F. Supp. 219 (E.D. La. 1966). Although Harvey was never appealed, there are two reasons to doubt its continuing validity. First, District Judge West rendered his opinion on February 4, 1966, a month after the oral arguments in South Carolina v. Katzenbach, 383 U.S. 301 (1968) (see note 62 supra), and a month before the Supreme Court's decision in that case. Although the Court stated that South Carolina's attack on Section 11 was "premature," 383 U.S. at 317, it uplicld scctions of the Voting Rights Act which established a broad system of supervision and control by federal officials over state elections, including, by necessity, the actions of private citizens.

Second, Judge West held Section Il(b) unenforceable under a narrow reading of the fifteenth amendment. In his view, Congress can legislate against denial of voting rights on account of race "by the United States or by any State" but not by private citizcns. (In Harvey, defendants were plantation owners accused of terminating sharc-cropping and tenant farming agreements and evicting Negroes who registered to votc.) Under the Court's decision in South Carolina $v$. Katzenbach, Congress appears to have the power to legislate against private conduct as well as state action if that is necessary to enforce the fifteenth amendment. See Cox, Constitutional Adjudication and the Pro. motion of Human Rights-Foreword to The Supreme Court, 1965 Term, 80 HARv. L. REv. 91, 102 (1966).

Whatever is taken to be the rule regarding discrimination under the fiftenth amend. 
ingly wrongful challenge, ${ }^{68}$ made with the intent to deter the free exercise of the franchise, a violation of Section $11(b) .{ }^{09}$ Injured voters can also collect damages under the federal statute which forbids interference with rights and privileges protected by the Constitution of the United States. ${ }^{70}$

ment, similar language in the fourteenth amendment has been consistenty interpreted to cover basically private action. See Black, "State Action," Equal Protection, and California's Proposition 14-Foreword to The Supreme Courl, 1966 Term, 81 HARv. L. RE. 69 (1967). In United States v. Guest, 383 U.S. 745 (1966), six Justices expressed the vicw that under the enforcement provisions of the fourteenth amendment, Congress could legislate against private as well as state action which deprives individuals of cqual pro. tection. Therefore, Harvey need not bar an application of Section 11(b), rend turough the fourteenth amendment, to non-racially-motivated intimidation of voters by private parties wielding the challenge power.

68. In addition to private citizens, Section $11(\mathrm{~b}) \mathrm{might}$ be applied to ministerial clection officials who lack the power actually to "refuse to permit" a person to vote and therefore would not come within 11(a). Since the ministerial officials are agents of the state, there would be no objections on "state action" grounds to the application of the statute to them.

69 . In light of legal developments over the past 95 years the Supreme Court is prob. ably prepared to reverse the position it took in United States v. Reese, 92 U.S. 214 (1875). In that case the Court struck down a federal statute which penalized election officials who wrongfully refused votes in local elections. The Court held that before the adoption of the fifteenth amendment the states could draw up voting rules without restriction and the amendment allowed Congress to intervene only when "the wrongful refusal [of a person's vote] . . . is because of race, color or previous condition of servitude." Id. at 218. However, the present Court's firmer commitment to the impleinentation of equal protection and more realistic view of the voting process would probably lead to a different outcome today. Congress's certain power to regulate harmful conduct not spring. ing from racial prejudice in federal elections (see note 61 supra) gives rise to an implied power to regulate other elections. Since both federal and non-federal (local or statc) elections are run by the same state machinery and are likely to be indistinguishable to the ordinary voter, intimidation (by officials or private citizens) which occurred at local elections and went unremedied by federal intervention would affect the free exercise of the franchise at federal elections. The voter who, in one case, found no federal protection for his right to vote would have little reason to presume that his next attempt to vote would fare any better.

In passing Section 11(b) of the 1965 Voting Rights Act, Congress explicitly recognized the importance of uniformity:

Thile Article I, Section 4 and the implied power of Congress to prevent corruption

in elections normally apply only to federal elections, and [Section 11(b)] applies to

all elections, these powers are plenary within their scope, and, where intimidation

is concerned, it is impracticable to separate its pernicious effects between federal and local elections.

2 U.S. Code Cong. \& Admin. News, H.R. 436, 89th Cong., 1st Sess, 2402 (1965).

70. 42 U.S.C. $\$ 1983$ (1964). Criminal prosecution for deprivations of rights or conspiracies to that end are authorized by 18 U.S.C. $\$ \S 241-42$ (1964).

The right to vote for a federal offce holder, in primary as well as general elcctions, has been repeatedly affrmed as a right secured by the constitution and laws of the United States. United States v. Classic, 313 U.S. 299 (1941); Guinn v. United States, 238 U.S. 347 (1915). Until recent years a debate raged among scholars and judges over whether the right to vote in state or local elections is a constitutionally guarantecd right or mercly a privilege granted by the states. Kommers, The Right to Vole and Its Implementation, 39 Notre DAME LAw. 368 (1964). For a time the prevailing view was represented by the opinion in Turman v. Duckworth, 68 F. Supp. 744, appeal dismissed, 329 US. 075 (1946): "The Constitution of the United States has nothing to do with state clections, save as specially provided in certain of the amendments." Id. at 748. A significant modificition in attitude appeared in Lassiter v. Northampton City Bd. of Elcctions, 360 U.S. 45 (1958), where the Court, in upholding the power of a state to set nondiseriminatory "standards" for the "right to vote," declared that "the right of suftrage is established 
Nevertheless, the invocation of federal statute does not offer a solution to the problems posed by wilful misuse of the challenge procedures created by the states. The national government has neither the resources, the will, nor, at present, the statutory power to police every polling place in the nation. Federal criminal statutes are subject to most of the weaknesses ${ }^{\tau 1}$ which make any post-election sanction only a partial cure for perversion of the challenge power. Moreover, any successful remedial system will almost certainly require a simple process for determining the validity of rights of challenged voters. ${ }^{72}$ Since the states have major responsibility for the administration of elections, ${ }^{73}$ it is not only logical but proper that they, without relying on federal measures, should develop and employ controls over the use of voter challenges.

\section{Designing A Model Statute}

\section{A. Goals and Limitations}

A voter challenge statute must accommodate two conflicting aspects of society's interest in fair elections by guaranteeing every qualified

and guaranteed by the Constitution." Id. at 51, citing Ex parte Yarbrough, 110 U.S. 651 (1884). "The principle . . that the protection of the exercise of this right is within the power of Congress, is as necessary to the right of other citizens to vote as to the colored citizen; and to the right to vote in general as to the right to be protected against discrimination. The exercises of the right in both instances is guaranteed by the consti. tution and should be kept free and pure by congressional enactments whenever that is necessary." Id. at 655. In Reynolds v. Sims, 377 U.S. 533 (1964), the elevation of the right to vote to the level of "a right or privilege protected by the Constitution," apparcntly moved to completion. "The right to vote frecly for the candidate of onc's choice is of the essence of a democratic society, and any restrictions on that right strike at the heart of representative government." Id. at 555. As the constitutional dimensions of the right protect it from being denied because of dilution or debasement by malapportioninent, they should guard against its denial by intimidation or coercion through the misuse of voter challenges.

71. E.g., strict construction, difficulty of proving malice, and so on. See pp. 669.71 supra. On the other hand, U.S. Attorneys are less likely to be subject to thic political pressures which affect the local district attorney.

72. The difficulties which the federal government faces when it attempts to regulate voting can be seen in the complicated procedures established by Section 12(c) of the 1965 Voting Rights Act, 42 U.S.C. § $1973 \mathrm{j}(\mathrm{e})$ (Supp. II, 1966), for counting votes of persons wrongfully excluded from the polls. Significantly, the section only has effect in those political subdivisions in which a "Federal examiner" has been stationed pursuant to Sections 3(a), 4(a), and 6 of the Act. 42 U.S.C. 1973a(a), -b(a), -d.

The Voting Rights Act (Section 9) also establishes a method by which any person registered by the federal examiner can be "challenged." This challenge does not, however, take place at the polls, but must be made "within ten days after the listing of the challenged person is made available for public inspection" and be supported by "the affidavits of at least two persons having personal knowledge of the facts constituting grounds for the challenge." A hearing officer appointed by the United States Civil Scr. vice Commission shall determine the challenge within fifteen days after it has been filed, and a "clearly erroneous" decision of the hearing officer can be reversed by the appro. priate U.S. Court of Appeals. 42 U.S.C. \$ 1973g (Supp. II, 1966).

73. Some sections of the 1965 Civil Rights Act introduced the federal government for the first time into some involvement, though still indirect, with local election adminis. tration. See, e.g., 42 U.S.C. $\$ \S 1973(\mathrm{a})$ to -(d), -(f) to -(g), (Supp. II, 1967). 
voter the right to cast a ballot while limiting qualified voters to a single ballot and preventing unqualified persons from voting. The goal of a model statute must be a reasonable balance between an overly restrictive system, in which the challenge procedures can be misused to prevent or deter those qualified from voting, and an overly permissive one, which might allow voting by non-residents, felons, and incompetents, and "voting the graveyard." 74 The characteristics of voting officials and of voters themselves suggest that the voter challenge system must be simple and largely self-regulating if it is to achieve this goal and still maximize the speed with which final and accurate election results can be obtained. Consequently, certain realities of the electoral process suggest objectives and limitations which must be recognized in designing a model statute.

First, polling officials are usually political appointees who possess limited capacity to make complex judgements and who are often open to outside influences. ${ }^{75}$ Decision-making is rendered even more difficult by the atmosphere of conflict and tension that frequently pervades a polling place. ${ }^{76}$ Therefore, local officials should be given a minimum of

74. A number of courts and commentators hare pointed out that if a choice has to be made, it is preferable to allow a fraudulent vote to get by cvery so often than to disenfranchise any qualified voter at any time.

I think it would be a far greater menace to the security of this constitutional right

[of voting] if the law regulating its exercise might prevent the rote of a citizen,

duly qualified to cast it, from being received and counted, than that some fraud might be practiced by a false personation. For in the one casc, there vould be disenfranchisement of the elector; while in the other, for the wrong done to the people, or to the individual, penalties and remedies are provided, and tribunals exist for their enforcement against a wrongdoer, and for the establishment of the right."

People v. Bell, 119 N.Y. 175, 179, 23 N.E. 533, 534 (1890). See also 4 Or. ATt'v GeN. C.I. 333,335 (1944), advising on the reasons for the state's ministerial system:

The boards and inspectors must not permit the hearing of belated inquiries into qualifications of challenged voters to so disrupt the procedure of voting as to deny other persons their right to vote. The chief duty of the Boards on clection day is to supervise voting, and not to take over the functions of the registrar of voters or the courts. The law contains ample provisions for dealing with the fraudulent voter. The danger that an occasional improper vote may be cast must be veighed against the greater evil of disenfranchising qualified voters by dilatory procecdings at the polls.

75. See J. Harris, supra note 4, at 9: "In many cities the election officer is the worst spoils ridden office of all, and it is not uncommon for it to be the dumping ground for incompetents who cannot be placed elsewhere. In many cities with strong political organizations the precinct officers are not merely incompetent, they are often corrupt ... "; id. 148-49: "The registration and election officials, from top to bottom, are fre. quently incompetent and sometimes corrupt. The bitterest and most unscrupulous partisans are placed in charge, whereas public policy should indicate that they kecp hands off." There is little reason to think that the situation has changed radically in the twenty-five years since these observations were made.

76. Since most precinct boards have representatives of most of the candidates present. arguments and heated discussions are common. This an be seen in the New Haven case, where representatives of the insurgent faction fought bitterly with the organization officials. For discussion of the undesirability of asking for decision-nuaking under such circumstances, see People v. Bell, 119 N.Y. 75, 23 N.E. 533 (1890). 
discretion regarding voter challenges. ${ }^{77}$

Second, criminal sanctions alone are not a satisfactory safeguard against misuse of the challenge power. ${ }^{8}$ Civil damage actions and provisions which make the use of challenges worthless as an instrument of fraud are needed to prevent the statute's restrictive provisions from being used to deprive qualified voters of their ballots.

Third, most citizens have little interest in politics ${ }^{70}$ and want to vote as quickly and effortlessly as possible. ${ }^{80} \mathrm{Few}$ will care about the details and requirements of election statutes or be interested in anything (whether it be voting or following up a complaint after election day) which requires extensive knowledge of the law. Therefore, the statute ought to minimize the possibility that impediments can be placed in the way of a qualified voter's exercise of the franchise and ought to provide a system of post-election legal remedies which operates so far as possible without initiative on the part of the voter.

Fourth, any statute should provide a system which attempts to avoid both the necessity of judicial intervention to overturn the election results or to call a new election and the possibility of long periods of time during which the election results are uncertain and provisional.

\section{B. Suggested Provisions for a Model Statute}

\section{Section 1. Grounds for Challenge}

Failure to meet any of the following qualifications is a ground upon which a person attempting to vote may be challenged: [Grounds listed.] $]^{\mathrm{si}}$

77. Election officials do not necessarily oppose such a move. In the words of Nicholas C. Bonadies, Chief Registrar of the City of Hartford, Connecticut: "I wish they would take all discretion away from all election officials. We'd be much better off if the statute would tell us what to do, and we do it, automatically. Things would be easier on us and better for the voters." Interview in New Britain, Connecticut, Dec. 14, 1968,

78. See note 38 supra on the political influences which lead many district attorncys not to prosecute.

79. A. Campbell, T. Converse, W. Millex \& D. Stokes, The American Voten, 168.87, 215-65 (1960). See generally B. Berelson, P. LAzarsfeld \& W. MicPheE, Voting (1954); V. O. KeY, JR., Public Opinion and AMErican Democracy (1961).

80. Even such minor hurdles to voting as the provision of fewer registration opportunities has been shown to reduce the number of voters significantly. Kelley, Ayrcs \& Bowen, Registration and Yoting: Putting First Things First, 61 AMr. Pol. Scr. REv. 859 (1967).

81. Other model codes have been presented in the past. The Committee on Election Administration of the National Municipal League, for example, proposed a challenge system similar to New York's, with provision for questioning by the clection officials of the challenged voter and a final general oath before voting. See J. HIARnts, supra note 4, citing Specification 29 (at 49 ) and Section 14 of the League's proposal (at 87). The League's proposal, however, is fairly general, leaving most of the ramifications of voter challenges untouched.

82. Throughout the Model Statute, material which must be filled in on a state-by. state basis appears in brackets. 


\section{Comment}

This provision will enable both the voter and the challenger, whether official or private citizen, to ascertain quickly, easily, and with little chance for confusion the precise grounds for which challenges are permitted. It is designed to remedy a weakness of current election law in many states which leaves the grounds for challenging wholly unspecified. ${ }^{83}$

In filling in the complete list of possible grounds for challenge in this section, each state will have to choose between deriving the list directly from the qualifications needed to register plus those appropriate to protecting the ballot box on election day (for example, repeated voting and betting on election day ${ }^{84}$ ) and limiting the basis for challenge more narrowly. ${ }^{85}$ For instance, a state which did not care to use the challenge process as a check on the accuracy of the registration books might specify only "nonregistration," "wrong identity," "lack of residence," and "repeated voting" as grounds for challenge at the polls, under the presumption that the registration procedure would screen out those who were unqualified for other reasons, such as being underage, illiterate, an alien, or a felon.

If some of the voting requirements vary for different kinds of elections, a state could of course list these grounds in conditional form. ${ }^{86}$

\section{Section 2. Duty and Power to Challenge}

(a) Officials.-Members of local election boards shall challenge a voter whenever they have reasonable grounds to believe that the voter is not qualified under the laws of this state. No degree of suspicion less than reasonable grounds for belief shall justify a challenge.

(b) Citizens.-Any citizen may challenge a voter if he has reasonable grounds to believe the voter is not qualified under the laws of this state.

\section{Comment}

The standard of "reasonable belief" provided here serves to require initiative by election officials as well as to restrain it; it defines a level of suspicion above which an election official must challenge and below

83. See note 12 supra.

84. E.g., CaI. ELECTION CODE $\$ 14240$ (West 1961).

85. E.g., VA. CODE ANN. \$ 24:16-4 (1964), as amended (Supp. 1968).

86. E.g., ORE. Rev. STAT. $\$ 247.410$ (1968) (persons who are not state residents long enough to be qualified to vote for state offices may nevertheless vote for federal offices). 
which he cannot challenge. ${ }^{87}$ While, like all standards, it is subject to differing interpretations, it provides a basis in laymen's language upon which an election official can judge his own determinations with a good deal of certainty. Thus, an election official will be aware that he must have reasons to justify (perhaps in court) his use or non-use of the challenge power.

The section which permits challenges by citizens is designed to assure that official laxity can be checked by private initiative. ${ }^{88}$ Most states limit those who can be in the polling place to officials, party challengers or checkers, and persons in the process of voting. Consequently the average citizen would not be in a position to exercise the challenge power over every voter. The use of the challenge is not restricted to the day of the election, however, so citizens who find errors on the election rolls prior to polling day can make their challenges to the registrar of voters. ${ }^{89}$ And, the Model Statute should be taken as endorsing a liberal view of current state laws on citizens' presence at the polls, so that a voter should be allowed into the polling place to challenge the right of a particular person to vote.

\section{Section 3. Challenge Procedure}

(a) Challenges at the Polling Place.-

(1) If the challenger is present at the polling place, he shall state aloud to the challenged voter the grounds for the challenge.

(2) The [official presiding at the polling place ${ }^{00}$ ] shall then read the statutory voting qualifications applicable to the challenge aloud to the challenged voter. He shall ask the voter whether he understands the statutory qualifications and whether he believes that he meets the qualifications. If the voter's answers are affirmative, the [presiding official] shall explain the proce-

87. See 4 OP. ATr'Y GEN. CAL. 333 (1944), in which the Attorney General of California read "probable cause" into that state's challenge procedure. His opinion, however, was made in the context of a quasi-judicial system; he said that the local election boards should overrule, as not being made "in good faith," challenges which they believed are not supported by "probable cause." The opinion also authorized the boards to overrulc summarily all challenges if the number of voters challenged is so great as to clearly pro. duce long delays, so as to be a denial of the right of any qualified voter to cast his batlot. To deal with this problem, the Model Statute (which establishes a ministerial system under which no challenge is summarily overruled or accepted) penalizes knowing devi. ation from its "reasonable belief" standard with criminal and civil penalties. Sce Model Statute \& 6 \& comment infro.

88. While private citizens may be able to prevent some voting fraud which is the product of official complicity with unqualified voters, primary reliance should not be placed on the challenge prodcedure for this end, but should continue to rest on other anti-fraud provisions of state election laws.

89. See Model Statute § 3(b) infra.

90. Usually called the "Chairman of the Election Board." 
dures of the following subsections and ask the challenged voter whether he wishes to vote.

(3) If the challenged voter indicates that he does wish to vote, the [presiding official] shall record on a numbered affidavit (i) the names and addresses of the voter and the challenger, (ii) the qualifications challenged, and (iii) a summary of the reasons for believing that the challenged voter fails to meet the qualifications.

(4) The challenger shall then sign the affidavit following this statement: "I do hereby challenge the right of the above-named person to vote because, for the reasons set forth above, I believe that he lacks the specified voting qualifications." If the challenger, after having the opportunity to alter to his satisfaction the summary of the grounds for his challenge, refuses to sign this statement, the challenge shall be considered to be withdrawn, and the voter shall be permitted to vote on an ordinary ballot. Such withdrawal does not exempt the challenger from liability under Section $6(b)(1)$ of this Act.

(5) If the challenger signs the affidavit provided for above, the voter shall then sign following this statement: "Having read this affidavit I do hereby swear that to the best of my knowledge I meet the qualifications set forth above."

(6) The affidavit shall carry the following in boldface type: "Warning: False statements on this affidavit may lead to criminal prosecution."

(7) When the voter has signed the affidavit, he shall be given a special ballot labeled "Challenged Ballot" with an identifying number identical to that on the affidavit he has signed; he shall then be entitled to vote using this ballot.

(8) Challenged ballots shall be counted along with all other ballots, and shall then be delivered to the proper officials as specified in Section 5.

(9) If the voter admits that he does not meet the qualifications upon which he has been challenged or declines to cooperate in the completion of the affidavit, he shall not be permitted to vote.

(b) Challenges Prior to Election Day.-A challenge may be made prior to election day at the office of the [head election official for the locality ${ }^{91}$, who shall record on a numbered affidavit the information required in subsection (a)(3), have the challenger sign as required in subsection (a)(4), and send the affidavit and the numerically 
matching ballot to the appropriate polling place with the other election supplies; when the voter named on the affidavit presents himself to vote, the [presiding official] shall read aloud to the challenged voter the grounds as summarized on the affidavit, and shall, in all other respects, follow the procedures and requirements as outlined in subsection (a).

\section{Comment}

The procedure outlined here provides election officials with ministerial powers alone. There is no requirement for an on-the-spot production and inspection of documents, handwriting comparison, or other investigation. While the challenger, whether an official or a citizen, must be able to state reasonable grounds for the challenge, the issuance of a "Challenged Ballot" does not depend on anyone's determination of how reasonable the grounds are. ${ }^{22}$ This procedure reduces the likelihood that an official's innocent error or willful fraud will prevent a qualified elector from having his vote counted. The system also minimizes delay in the voting process which might otherwise discourage the voter who does not wish to expend too much time or energy in casting his ballot.

The keystone of this ministerial system is the use of the affidavit. The procedures outlined here guarantee that all voters can vote if they choose to. ${ }^{93}$ As provided in Section 5 below, a voter's ballot can be disallowed only after his qualifications have been fully investigated by a body with greater expertise than the local officials at the polls, operating under conditions more favorable to a rational decision..$^{04}$ As a safeguard against the misuse of the affidavit system, the non-qualified voter will have to lie under oath before he is given a ballot, in circumstances which make prosecution easy. ${ }^{95}$ The deterrent effect of an affidavit re-

91. Usually called the "Registrar of Voters."

92. When acting in his capacity as challenger, an election officer must of course makc an initial decision-whether or not he has "reasonable" ground to challenge. But whatever the results of that decision, the officer's conduct in his ministerial capacity is not affected, and the issuance of a challenged ballot to any voter who has expressed his willingness to sign the affidavit is automatic.

93. It is obvious that the effectiveness of this statute as a bar to voter deprivation depends on widespread voter education; the possibility will continue to exist that indi. vidual voters, uninformed about their rights, will be intimidated by the challenge and will leave the polling place without insisting on voting, even though the Act requires in Section 3(a)(2) that the voter be apprised of the exact ground for the challenge and his right to a special ballot notwithstanding the objection.

94. Cf. Lane v. Mitchell, 153 Iowa 139, 142, 133 N.W. 381, 383 (1911): "The constitutional right to vote is of high value to voters generally, and they should not be de. prived of it, except after full investigation by a tribunal with authority to make such an investigation."

95. On the availability of perjury statutes as a basis for prosecution, sce Goctcheus v. 
quirement, as opposed to policing by third parties, has been much debated. The Internal Revenue Service bases its tax collections on selfpolicing with various penalties for filing false returns. Jurisdictions which have recently changed from an investigative to an affidavit system in the determination of eligibility for public assistance have found no increase in falsification of applications. ${ }^{90}$ The deterrent effect of the false statements provisions in the case of voter challenges might well exceed those of the income tax returns and welfare application because the percentage of the affidavits actually investigated will probably exceed that of either of the other two systems.

The Model Statute does not provide for challenges to absentee ballots because the statute focuses on the use of the challenge power to intimidate prospective voters. As the absentee voter is unaware of any challenge of his right to vote, the problem of coercion does not arise. While the penalty provisions of Section 6 are therefore inapposite, it would be advisable to have the Board of Election Inquiry pass on challenged absentee ballots so that they will receive the same consideration as other challenged ballots. Such a procedure could easily be incorporated into a state's absentee ballot provisions, since most states provide that the ballot be returned in an envelope on which the voter attests to his right to cast the ballot. ${ }^{97}$ If the ballot were challenged, the voting officials could mark the ballot and envelope with an identifying number and record the challenger's name and grounds for challenge on the envelope, which could perform the function of the affidavit under the Model Statute.

Mathewson, 61 N.Y. 420, 436 (1875): "Most of the questions that may tend to excite a momentary irritation caused by the challenge are disposed for the time being by (the voter's) oath. If he willfully swears falsely, he is liable, on conviction, to a suitable punishment." See also People ex rel. Stapleton v. Bell, 119 N.Y. 175, 187-88, 23 N.E. 533, 537 (1890):

Practically, the law leaves it to the conscience of the person offering to vote to decide whether he can or will do so when his right is challenged ... The law provides for the punishment of a person who falsely personates a registercd voter; and the proposed elector, who is challenged for that cause, if he persists in his attempt to vote, may accomplish his purpose, but at the peril consequent upon false swearing and of false personation.

See also 4 Or. ATr'y GEN. CAL. 333, 335 (1944).

96. See Simonds, Declarations and Incentives: New Approaches to Public Assistance, Public Welfare, Jan. 1968, at 67, 70: "Based on our experience to date, the self-declaration system has had no effect on the incidence of errors nor the percentage of incligibles; on the contrary, there is some evidence that there may be cven fewer errors and fewer ineligibles with self-declaration." See also Note, Eligibility Determinations in Public Assistance: Selected Problems and Proposals for Reform in Pennsytuania, 115 U.

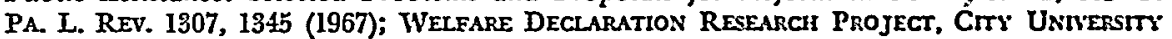

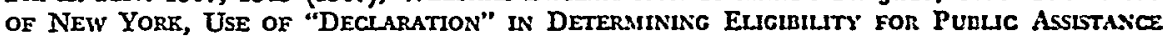
(1968).

97. See, e.g., N.Y. Election LAw \& 117 et seq. (Mfckinney 1964); TEx. Eurction Code art. 5.05 (1967). 
Section 4. Board of Election Inquiry

(a) Party Nominees.-From a list of five nominees submitted by the state chairman of each political party, the [chief election officer of the state ${ }^{88}$ shall appoint for three-year terms to the Board of Election Inquiry two members of each political party which received more than 20 per cent of the votes cast for any statewide office in the election immediately preceding the date of appointment.

(b) Nonpartisan Member.-At their first meeting, the members of the Board thus appointed shall appoint one additional, nonpartisan member to the Board for a term concurrent with their own, but no other business shall be conducted until this member has assumed his duties; if the Board fails to appoint this nonpartisan member within one month, the [chief judge of the highest court of the state] shall immediately appoint the nonpartisan member; in this section a "nonpartisan" means a person not affiliated with or registered as a member of any political party.

(c) Vacancies.-A vacancy on the Board shall be filled in the same manner as the former member was appointed under subsection (a) or (b).

(d) Holding Concurrent Office.-During his term of office, no member of the Board shall be an officer of any political party organization or hold any elective or appointive office in federal, state, or local government, other than membership in the judiciary.

(e) Powers and Duties. - The Board shall be able to subpoena records and witnesses, administer oaths, take sworn testimony, formulate and enforce rules of procedure, and issue adjudicatory orders; shall employ and direct such investigatory staff as the legislature shall from time to time provide for; and shall make final determination of the validity of the challenged ballots submitted to it within one month following the election. A majority vote of the entire Board shall be required to exclude any challenged ballot.

(f) Proceedings.-All hearings of the Board shall be open to the public, and the record of the Board's determinations shall be available for inspection by the public; witnesses before the Board may consult with counsel.

98. In many states, the chief election officer is the secretary of state, who is clected in a statewide election. 


\section{Comment}

The existence of a Board of Election Inquiry provides a method for ruling on affidavits as a matter of course and without asking the voter to take any initiative whatsoever. ${ }^{99}$ Further, it is more practical to give such a Board the responsibility of investigating and passing on affidavits, rather than burdening the prosecutor's office with investigating them and the courts with ruling on them. ${ }^{100}$

Insuring that the swing member of the Board will be nonpartisan and that among government employees or officeholders only judges may be members of the Board should help to raise the Board itself above politics. Since the Board members perform a state-wide function, in reaching their determinations they will probably be less subject than the district attorneys to the sorts of political influences which are strongest at the local level and which interfere with fair and unbiased consideration of the facts in voting rights cases. Moreover, proceedings and decisions by the Board are open to public scrutiny as further assurance of honest determination of challenges.

\section{Section 5. Determination of Election Result}

(a) Non-Challenge Contest.-If the number of challenged ballots is less than the number of votes by which the total vote for the leading candidate exceeds that of his closest opponent, then-

(1) The leading candidate shall immediately be declared the winner of that election contest by [the appropriate body'01], and

(2) The affidavits corresponding to such ballots shall be delivered to the appropriate district attorney.

(b) Challenged Contests.-If the number of challenged ballots is greater than the number of votes by which the total vote for the leading candidate exceeds that of his closest opponent, then-

(1) The challenged ballots and corresponding affidavits relevant

99. This system is superior to the Washington system, which requires that the voter or the challenger request an investigation. See p. 667 supra.

100. Because of the importance of achieving finality of election results, no judicial review of Board decisions is provided for. Those states which already provide for judicial review of determinations of state agencies and which do not wish to provide an exception for the Board of Inquiry here should at least set a specific time limit for appeals and decisions on such appeals. The judicial relief of mandamus should nonetheles be preserved for use against a recalcitrant Board which failed to perform its statutory duty to pass on all challenged ballots within 30 days following the clection. See Model Statutc $\S 5(b)(5)$ infra. This will serve to prevent a Board fron using a 2.2 split vote with one abstention as an excuse not to act; the Board will have to establish a rule as to the mean. ing of such rotes (e.g., any motion, such as "This Challenged Ballot shall be excluded." fails to pass, if it receives an evenly divided vote).

101. Usually called the "Board of Canvassers." 
to each such contest shall be delivered by [the appropriate local election official ${ }^{102}$ ] to the Board of Election Inquiry as soon as the ballots have been counted;

(2) Each such contest shall be known as a "challenged contest," and no declaration of the winner shall be made until the Board completes its findings;

(3) The Board shall investigate the statements made in each affidavit to determine the validity of the matching challenged ballot; by registered mail it shall offer each challenged voter, challenger and [official presiding at the election place ${ }^{103}$ ] an opportunity to appear at the hearing on his affidavit, and if necessary it may subpoena him to appear;

(4) When its investigation reveals that the voter was properly challenged, the Board shall cancel the ballot which bears the same identifying number as that voter's affidavit and shall subtract the votes appearing on that ballot from the totals of the appropriate candidates in all challenged contests;

(5) The Board shall determine the validity or invalidity of every affidavit in a challenged contest within 30 days after the election; it shall then declare the final result for that contest, and the candidate receiving the largest number of legal votes shall be declared the winner; and

(6) In the case of each affidavit which discloses an erroneous challenge or a voter's false statement, the Board shall deliver to the appropriate district attorney all evidence relating to such false affidavit, and the district attorney shall, in each case, either prosecute under Section 6 the person who has made false statement or an erroneous challenge, or he shall submit to [the appropriate committee of the state legislature] a public report explaining his failure to prosecute.

(c) Propositions and Referenda.-As used in this section, the term "candidate" includes the affirmative and negative positions ("Yes" and "No," or "For" and "Against" votes) on propositions and referenda.

\section{Comment}

This section emphasizes the importance of achieving finality in the

102. The local official to whom the actual ballots are returned is usually the Registrar of Voters.

103. Usually called the "Chairman of the Election Board." 
election result as quickly as possible. In a great many cases, the number of people challenged will not be large enough to affect the result of the election; ${ }^{104}$ therefore, it would be unnecessary to delay announcement of the result until all challenges have been investigated. Also provided here is a method of ruling on all affidavits and declaring a new winner, if such is the case, without the necessity of calling a new election. The Board is able to isolate the illegal ballots, which bear the same number as the affidavits, and subtract those votes from the appropriate candidates. ${ }^{105}$ The system proposed here seems less offensive to the concept of the secret ballot than the Maine system, which utilizes no affidavits. ${ }^{108}$ There, the name of the challenged person is written directly on the ballot, while in the proposed system, the ballots are identified numerically. Only when the vote is found to have been cast illegally does the Board of Inquiry match up a numbered affidavit (on which the unqualified voter's name of course appears) with a numbered ballot.

While the initial investigation and hearing, as well as all determinations relating directly to the election results, are placed in the hands of the Board, prosecution for misuse of the challenge or voting with-

104. Because of the "reasonable belief" standard there will probably be many fewer challenges than is presently the case. Therefore, in most elections there will in all likelihood be no contests in which the number of challenged ballots is large enough to affect the outcome. The most burdensome task which could fall on the Board of Election Inquiry would be to have to review all challenged ballots, which would occur if the close election contest were for a state-wide office. Lange states may find that it may be necessary to divide the state geographically and establish an additional Board of Election Inquiry to handle the work load expeditiously. However, the creation of more than two Boards would be inadvisable as the elevated and non-political nature of the statc-vide body would be significantly reduced as its jurisdiction is decreased and it gets closer and closer to local politics.

105. This remedy is an improvement over the one available in jurisdictions which have numbered ballots but which require judicial determination of election disputes. Typically, the election law in these states provides that the ballot of the challenged voter be marked (in a concealed manner) with the number corresponding to the voter's poll list number. E.g., MICH. CoMI. LAws ANN. $\$ \S 168.745-46$ (paper ballots), 168.783 (voting machines) (1967); WWIs. STAT. ANN. $\$ 6.95$ (1967). If an election is contested, the judge may examine the ballots to identify by number those which were cast by persons whom he has determined were not qualified to vote; he must "immediately" concenl the identifying numbers again. Mrch. Coxp. LAws ANN. $\$ \$ 168.747-49$ (1967). It is unclear whether the judge in a quo warranto proceeding, id. \$ 600.4505 (1968), Wis. STAт. ANN. \& 294.04 (1958), can exclude the ballots of unqualified voters. A court clearly has the power to exclude or receive improperly marked ballots, Hawkins v. Voisine, 284 Mfich. 181, 278 N.W. 811 (1938); Attorney General ex rel. Carpenter v. Ely, 4 Wis. 420 (1855-50), but there is specific statutory provision for the way these ballots should be handled in the counting process by the board of canvassers. MIICF. CoגP. LAws ANN. $\S 168.803(1)$ (1967), Wis. STAT. ANN. \& 75I(2) (1967). See also Mirch. CoMp. LAws ANN. \& 168.792a(8) (I967).

106. The present system in Maine has a number of other disadvantages which the Model Statute attempts to overcome. A voter challenged in Maine does not have to take a sworn oath as to his qualifications; at trial this would make it more diffucult to prove that he voted knowing that he did not meet the qualifications which had been challenged. There are no provisions for the investigation of challenges in cases not before the Governor's Council, and there is no standard of "reasonablenes" imposed upon the exercise of the challenge. ME. REv. STAT. ANN. tit. 21, §§ 863, 925(1), 1212 (1965). 
out qualification is left to the district attorneys. In cases in which the challenges could not have affected the election's outcome, the prosecutor has complete discretion on whether to investigate or bring charges. This decision will doubtless be influenced by the number of challenges, the affidavits' reasonableness on their face, the general political climate in the locality, and particularly the degree of public concern over fraudulent voting practices. In cases in which the Board of Inquiry has first ruled on the affidavit, the prosecutor's discretion has been limited to the extent that he must explain his failure to prosecute to the legislative committee overseeing election laws. His investigation might have shown that although a false statement was made, the offending party did not act knowingly. This explanation would not, of course, alter either the accuracy of the Board of Inquiry's determinations or the continuing validity of the actions based on those determinations. Requiring that the explanation be public should serve to dissuade the district attorneys from withholding prosecutions because of political considerations. ${ }^{107}$

\section{Section 6. Griminal Sanctions and Civil Damages}

(a) False Affidavit.-Any voter who signs an affidavit and votes, knowing that he lacks the qualifications stated by the challenger on the affidavit, is liable upon conviction to imprisonment for 30 days or a fine of $\$ 100$, or both.

(b) Knowing Misuse of Challenge Power; Knowing Failure to Accept Vote.-

(1) Liability.-

(A) Anyone who challenges a qualified voter on election day knowing that he does not have reasonable grounds to believe that the voter challenged lacks the stated qualifications to vote, or

(B) Any election official who knowingly fails or refuses to challenge a person who lacks qualifications to vote, or

(C) Any election official who knowingly fails or refuses to accept the vote of a person who has expressed his willingness to sign an affidavit and cast a challenged ballot, or who in any other manner knowingly fails to follow the procedures and requirements of section 3 of this Act,shall be liable upon conviction to imprisonment for up to one year or a fine of up to $\$ 1000$, or both, and shall be civilly li-

107. See note 38 supra. 
able to the voter who has been wrongly challenged or deprived of his rights under this Act, or to any candidate who was defeated because votes were improperly excluded or received, for compensatory and punitive damages of not less than $\$ 50$ and reasonable litigation expenses.

(2) Effect of Conviction.-In a civil action under subsection (b) (1), proof that the defendant was criminally convicted for the conduct in question shall be conclusive on the issue of liability.

(3) Presumption for Unchallenged Votes.-In a civil action brought by a defeated candidate under subsection (b)(1), proof of knowing failure to challenge an unqualified voter shall give rise to the rebuttable presumption that the vote was cast for plaintiff's opponent.

(c) Negligent Misuse of Challenge Power; Failure to Accept Vote.-

(1) Anyone who signs an affidavit, as provided in Section 3(a)(4) of this Act, challenging a qualified voter without reasonable grounds to believe that the voter lacks the stated qualifications to vote, or

(2) Any election official who fails or refuses to accept the ballot of any qualified voter,-

shall be civilly liable to the voter who has been wrongly challenged or prevented from voting, or to any candidate who was defeated because votes were improperly excluded, for liquidated damages of $\$ 50$ and reasonable litigation expenses.

(d) Ineligibility for Offices.-Any person convicted under subsection (b) shall be ineligible to hold any elective or appointive position in town, city, county, or state government for ten years following the date of conviction.

(e) Statute of Limitations.-Prosecutions and civil actions under this section must be commenced within one year of the election in which the violations allegedly occurred.

\section{Comment}

Since the affidavit-challenged ballot system greatly reduces the likelihood of politically motivated misuse of the challenge procedures, the need for severe penalties is reduced. Nevertheless, the Model Statute, unlike the vast majority of election laws, does provide deterrents against abuse at each point in the challenge process, for two reasons. Even an attempted misuse of the election laws injures the public; and 
some persons may attempt to affect the election results by circumventing the affidavit system entirely.

As the ballot of an unqualified challenged voter can do no harm, subsection (a) provides comparatively light criminal penalties. ${ }^{108}$ The provision is applicable only when the voter proceeds to vote despite his knowledge that he lacks the qualifications on which he has been challenged; his lack of any additional qualifications would be dealt with under the jurisdiction's other provisions on voting fraud, as would the actions of any unqualified but unchallenged voter.

The major target of the penalty provisions is the election official or party pollwatcher who fails to perform his duties or who challenges persons in the hope that they will be dissuaded from voting at all. In addition to the criminal penalties, the model statute contains two standards of civil liability. ${ }^{109}$ The first covers those who knowingly misuse the challenge power. In arriving at its award of damages, above the minimum of $\$ 50$, the jury should consider not only the harm suffered by the plaintiff 110 but also the willfulness of the defendant's acts as indicating harm to the public. Since such a civil suit may follow a criminal action against the same defendant for the same conduct, the plaintiff is permitted to use the verdict in the criminal case ${ }^{111}$ as conclusive on the issue of liability in his civil suit.

108. If the perjury provisions in the jurisdiction cover "sworn" but unnotarized, out. of-court statements such as the challenged voter's affidavit, a voter who lied in order to vote might also be subject to the penalties for perjury, although this would sccm un. necessary and, as a matter of policy, unwise (in light of the improbability that his conduct will have harmed anyone).

109. The civil remedies are spelled out in detail in the Model Statute in the hope that they will be more effective as complements to the criminal penaltics than are the present common law remedies (see p. 669 supra), which apparently remain unknown to most voters. Most states leave the injured voter to rely on these remedics rather than conferring a statutory right to damages for election official misconduct. Even where the availability of a civil action is known, most voters are dissuaded from suing because of the difficulty of proving damages and the expense of bringing a suit. Cf. Morris v. Colorado Midland Ry., 48 Colo. 147,109 P. 430 (1910), discussed in note 46 supra. The Model Statute, however, provides for minimum liquidated damages as well as reasonable litigation expenses. Model Statute $\S \S 6(\mathrm{~b})(1), 6(\mathrm{c})$.

110. In light of the studies on the value most citizens attach to their individual vote (see note 79 supra), voters would most probably collect only the minimum fifty dollars damages. But see note 46 supra for an unusual assertion of higher valuation. A candidate, however, might be able to attach a much higher value to his loss of the election rcsult. ing from ballots which he can convince the jury were improperly received or excluded. The statutory scheme is designed to reduce the necessity for election contest suits bcing brought to upset election results. Clearly they are superfluous in the case of challenged ballots, which are handled by the Board of Election Inquiry; in the case of voters who were kept from voting or who were wrongly allowed to vote but not challenged, the existence of civil damages under the Model Statute provides an alternative to defcated candidates which may be more effective in detering official misconduct. Damage awards could be based on campaign expenses or other provable costs or, if it is not considered too speculative, the monetary value of the office lost.

111. This verdict would be arrived at according to the higher standard of "bcyond a reasonable doubt." An acquittal in the criminal case, therefore, would not be conclu. sive in the defendant's favor. 
The civil cause of action provided for in subsection (c) specifies liquidated damages of fifty dollars plus expenses ${ }^{112}$ for two kinds of violations. First, a challenger is permitted to question a voter briefly (in effect, "challenging" him without making a formal objection) when he has genuine doubts as to the voter's qualifications which do not amount to "reasonable grounds to believe" the voter unqualified."13 But, should the challenger go so far as to sign the affidavit, thereby causing the voter to cast a challenged ballot, 114 while lacking "reasonable grounds," he would run afoul of subsection (c)(1), which in effect, establishes a negligence standard. ${ }^{115}$ The second provision of subsection (c) imposes strict liability on election officials who refuse to allow any qualified person to vote. Full compliance with the statute is so important that this civil penalty will attach although the official claims to have acted only negligently and not wilfully. ${ }^{110}$

These civil remedies have been provided primarily to allow for civilian surveillance of the challenge procedures, in light of the possibility that political obstacles may forestall criminal prosecutions. In most instances, this role of "private attorney general" will be played by the voter who has been wrongly challenged or deprived of a ballot. The losing candidate ${ }^{117}$ has standing to sue only when the total of the

112. Should the plaintiff lose his case, the defendant election official under the law of most states would be entitled only to court costs, which do not generally include reason. able attorney's fees. The Model Statute accepts this limitation in order to minimize the financial risk for aggrieved voters and thus encourage them to bring suits. The limitation is not as harsh on the prevailing election official as it seems, for in most, if not all, cases local party organizations will provide attorneys or pay attorney's fees and other legal expenses. In the New Haven case, for example, the defendants were defended by an attorney supplied by the State Central Committee of the Democratic Party:

113. While this procedure may facilitate voting (since in many ases it will be casy to satisfy the challenger that his doubts, though raised in good faith, are misplaced. thereby allowing the roter to receive a ballot or vote by machine without going through a formal challenge), diligence must be exercised to make sure that challengers do not misuse their right to make these informal challenges. For instance, a pattern of baseless challenges on the part of an official or group of officials (especially should they annoy voters enough that some decide not to vote at all) would be clear evidence of challenges made with knowledge that they are unreasonable, 3 violation of Section $G(b)(1)(A)$.

114. The real danger is not that the voter will have to cast a challenged ballot, but that he will regard the whole procedure as being too much bother to go through mercly to vote. (See notes $79 \& 80$ supra.) Ironically, the qualified voter may be more casily dis. suaded from voting by a false challenge than the unqualified voter is by a legitimate one, since the qualified voter will likely be more piqued at having his right to vote wrongly doubted.

115. Thile Section 6(b)(1)(A) provides that the challenger is not liable if the jury is convinced that he believed his grounds to be reasonable when he voiced the challenge (a subjective standard), for liability to attach under Section $6(c)$ (I) the jury need only find that the grounds are, in fact, unreasonable (an objective standard).

116. The strict liability standard of Section $6(c)(2)$ is designed to encourage officials to comply fully with all their duties under the statute. Thus, in addition to damages for an outright violation of a voter's rights (such as complete refusal to allow a voter to cast even a challenged ballot), a qualified voter could collect liquidated damages from an official who, after the voter was challenged, failed to inform him of his right to cast a challenged ballot. See Model Statute \$§ $3(a)(2)$ to (a)(4) supra.

117. The reference in Section $5(c)$ of the Mrodel Statute to other meanings of the 
illegal voters who went unchallenged and the qualified voters who were turned away ${ }^{118}$ is larger than his opponent's margin of victory. Of course, the unique nature of the second offense in subsection $(b)^{110}$ makes civil recovery there quite unlikely. There being no injured voter, the only potential plaintiff would be a losing candidate who can show that the officials let people vote despite reasonable grounds to believe them unqualified, to a total large enough to affect the election result. So that the candidate will not have to rely on the testimony of hostile witnesses, subsection (b)(3) creates the presumption that persons who voted illegally did so for the plaintiff's opponent. ${ }^{120}$

The remedies which the Model Statute provides candidates who have been injured by misuse of the challenge procedures obviate the need for new elections in certain cases. ${ }^{121}$ Violations of subsections $(b)(1)(B)$ and $(\mathrm{C})$, however, go beyond the scope of the challenge process and touch upon instances of ordinary election fraud (officials permitting unqualified persons to vote or denying the ballot to qualified voters). Therefore, additional remedies for these infractions may be found in other provisions of state election law, particularly those dealing with election contests, which should remain in force or be enacted..$^{122}$

word "candidate" does not carry over to the penalty section; no citizen or group of citi. zens is empowered to sue should a proposition or referendum which thcy supported be defeated.

118. Although the voter who is wrongly challenged yet persists in voting can collect under Sections $6(b)(1)(A)$ and $6(c)(1)$, for obvious reasons the defeated candidate, under all provisions of Section 6 , can collect only if the qualified challenged voter (who must be able to testify that he would have voted for the plaintiff) did not cast his ballot. Also, the candidate cannot claim to be injured by the votes of unqualified challenged voters, since their ballots would have been removed by the Board of Inquiry before the final result was declared.

119. Subsection ( 1$)(B)$ is unique in that it punishes the failure of an official to chat. lenge an unqualified voter. There being no affidavit or challenged ballot, an action here would not come through the channels of the Board of Election Inquiry; instead, prosecution would depend on a complaint from an independent source.

120. The strength of the presumption can be seen in that to overcome it the defendant would have to rely on the testimony of persons whose credibility would be greatly reduced by the proof that they had voted illegally. The presumption is also necessary to avoid the fifth amendment problems which would be involved in the illegal voter's having to take the stand for the plaintiff to make out his injury; that he will have to do so if the defendant is to overcome the presumption leaves the burden on the defen. dant to persuade the voter to testify, which is proper in that the defendant's knowing failure to challenge an unqualified voter is culpable no matter for whom the voter cast his ballot.

121. For the advantages in avoiding new elections, see p. 672 supra.

122. Many state election contest provisions provide for the volding of an clection for a number of reasons, including "when illegal votes have been reccived, or legal votes rejected at the polls sufficient to change the result." N.J. STAT. ANN. \$\$ 19:29-1c, 19:29.9 (1964); CAL. Elections CODE \$§ 20021e, 20086 (1964); NEB. REv. STAT. \$\$ 32.1001, 92.1030 (1952); see p. 672 supra. Once the election is set aside, that section of the clection law dealing with filling vacant offices by judicial decree or through the calling of a special election becomes applicable. N.J. STAT. ANN. §§ 19:3-25 to -29 (1964); NE1. REv. STAT. $\$ \$ 32-1037$ et seq. (1952). However, for these remedies to be generally effective, it is necessary that the laws be modified so that the loser would not always have to prove that all the voters illegally excluded would have voted for him or that all those illegally accepted voted against him. Whenever the total number of votes illegally received or 
One addition to the civil liability sections might be a provision holding the state jointly and severably liable as defendant with convicted officials in order to insure that all successful plaintiffs will be able to collect the amount of damages to which they are entitled. ${ }^{123}$ This might also serve as incentive for the state to select its election officials more carefully. However, the drawbacks to state civil liability argue for its omission from the Model Statute. First, such a system might in fact be a disincentive to the state's criminally prosecuting an election official, since the resulting conviction would be conclusive on the issue of $\mathrm{li}$. ability in the civil suit, where the state would be a defendant. Secondly, the potential financial burden of civil liability may be politically unpalatable to state legislatures. ${ }^{124}$ In any event state liability is not needed for the process to operate successfully. The chief aim of the civil liability sections is punitive, not compensatory; they serve primarily to deter abuse of the challenge process by providing an avenue for "private attorneys general," not to repay voters or candidates an amount equivalent to the harm suffered.

Subsection (d) should be an additional deterrent to the election official who is tempted to use the challenge power for political purposes. Most such officials are either employed by government or are heavily dependent on temporary patronage jobs obtained through local political connections. They would undoubtedly be far less willing to harass individual voters for political purposes if it meant risking loss of future job opportunities.

It should be noted, however, that provisions for criminal and civil liability, no matter how severe, cannot be relied upon to prevent all abuse of the challenge power. Rather, the most effective deterrent is to make the use of the challenge power profitless as an instrument of election fraud. This statute attempts to attain that goal through the affidavit-challenged ballot system.

excluded exceeds the winning candidate's margin of victory, a new election should be ordered, unless the winning or losing candidate can prove that he would have received the highest number of legal rotes. See also Model Statute $\S$ G(b)(3) suprã; p. 692 supra.

123. While it is unlikely that most election officials would be judgment proof on a single $\$ 50$ judgment, some might be unable to pay the amounts adjudged in cases giving rise to punitive and compensatory damages for candidates, or in cases involving suits by a substantial number of voters.

124. Even without state liability the operations of the Board of Election Inquiry vould impose additional costs upon the state, though the state might anticipate savings on the costs of new elections (rendered unnecessary in cases involving illegal challenges alone). 


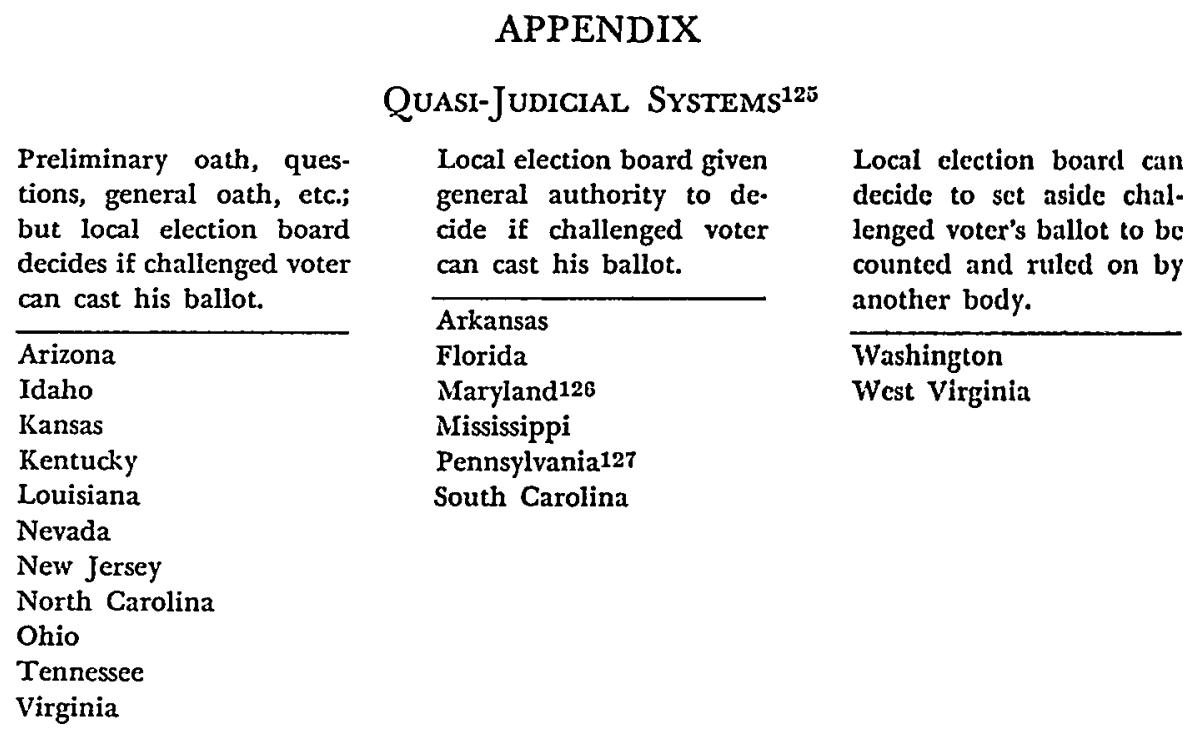

\section{Ministeriat Systems ${ }^{128}$}

Affidavit by voter and/or general oath.

Alaska
Georgia
Iowa
Massachusetts
Michigan
New Hampshire
North Dakota
Oklahoma
Oregon
Rhode Island
South Dakota
Utah
Wyoming

Preliminary oath, prescribed questions; general oath.

Colorado

Minnesota

Nebraska

New York

Wisconsin
Affidavit by challenged voter and other voters.

Alabama
Illinois
Indiana
Texas

Ballot counted; challenge determined by another body.

Maine
Challenges al. lowed only before election day.

\section{Hawaii} Vermont

\section{HYBRID SYSTEMS ${ }^{120}$}

California, Local election board decides all challenges except identity (challenged Montana voter can vote after taking an oath), "repeated voting" (can vote after

125. For specific citations see note 14 supra.

126. The only ground permitted for challenges in Maryland is identity.

127. Pennsylvania operates under a signature comparison system, with the members of the local election board determining whether the signature of the challenged voter is the same as that on the registration sheet.

128. For statutory citations see note 16 supra.

129. For statutory citations see note 19 supra. 
oath), and felony conviction (can vote after oath if an authenticated record of pardon or two witnesses are produced).

Connecticut Local election board decides all challenges except "repeated voting" (can vote if a sworn affidavit is signed).

Delaware Local election board decides challenges for identity; voter challenged for bribery can vote after taking an oath.

Missouri Local election board decides all challenges except identity (an vote after signing affidavit and getting affidavits from two precinct voters).

New Mexico If challenged for non-residence, ballot placed in scparate envelope, but counted; if name is omitted from list, can rote if affidavits of registration are presented; all other challenges detcrmined by the local election board. 